\title{
IMPACT OF STRENGTH TRAINING PROGRAM ON PHYSICAL FITNESS AND PSYCHICAL CONDITION FOR ELDERLY WOMEN
}

\author{
Vaiva Abramavičiūtė, Kristina Zaičenkovienė \\ Lithuanian Sports University, Kaunas, Lithuania
}

\begin{abstract}
Research background and hypothesis. There is a lot of research proving that physical activity improves psychical condition when there are symptoms of psychical illness. There is also a wide range of studies carried out investigating the impact of physical activity on physical abilities, but little is known how strength training program as a factor improves psychical condition and, at the same time, body composition, strength and endurance for elderly woman.

Research aim was to study the impact of an 8-week strength training program on physical fitness and psychical condition for elderly women.

Research methods were literature review, HADS to evaluate anxiety and depression symptoms, anthropometry, strength and endurance testing, statistical analysis of physical fitness and psychical condition indices.

Research results. In the period of 8-week strength training program we found that it had a positive impact on the indices in the experimental group compared to those in the control group. Psychical condition and strength results in experimental group were statistically significant $(\mathrm{p}<0.05)$; a significantly different change in aerobic endurance was measured during the $2 \mathrm{~min}$ step test. BMI and the body composition measures did not change statistically significantly.

Discussion and conclusions. The main finding is that an 8-week strength training period had a significant impact on psychical condition for elderly women. Moreover, strength training exercises improved upper and lower body muscle strength. Endurance improvement was observed during 2-min step test, but 6-min test results were insignificant $(\mathrm{p}>0.05)$. After the 8 -week training period, no significant differences in BMI and body composition were observed, although there was a slightly tendency of decrease in the experimental group.
\end{abstract} BMI.

Keywords: elderly women, physical fitness, psychical condition, 8-week strength training programme, HADS,

\section{INTRODUCTION}

A ccording to the population census of 2011 , carried out by the Department of Statistics of the Republic of Lithuania, over the recent decade, the population decreased by 440.6 thousand or by $12.6 \%$. At present, the population of Lithuania totalled to 3 million 43 thousand. As many as 650934 people in Lithuania are of the retirement age. Among them 215718 are men and 435216 are women. According to the Lithuanian Department of Statistics, there are 50\% more women of retirement age than men. Since 2001 the number of retired population has increased, respectively, from 20.2 per cent to 21.4 (Lietuvos statistikos departamentas, 2011).

It has been found that health related problems, living alone, poor communication and activity in social life, feeling of loneliness lead people to social disjuncture. Usually social disjuncture is the result of a certain psychical condition (Cornwell, Waite, 2009).

Clinical tests investigating the impact of physical activity on psychical conditions identified that constant physical loads had a positive impact on psychical condition, improved wellness and had 
a positive impact on mood and personal motivation. Inconsistent physical loads had a little impact on psychical condition and did not improve personal motivation. It was found that physically active adults had a lower risk of depression and cognitive decline compared with inactive or less physically active adults (Dunn et al. 2002; Elsawy, Higgins, 2010).

It is well known that aging is related with muscle atrophy. Aging is associated with the loss of muscle mass, muscle strength and muscle fibre mass. Scientific studies have shown that muscle mass tends to decrease gradually, the largest changes are observed from 50 up to 80 years of age. It has been found that muscle strength decline is much faster and more dramatic rather than the decline in muscle mass. The decline in strength and muscle mass has a tight relation with functional limitations and worsening of health condition (Williams et al., 2002; Faulkner et al., 2007; Koster et al., 2011).

The aim of the current research was to study the impact of an 8-week strength training program on physical fitness and psychical condition for elderly women.

\section{RESEARCH METHODS}

Research sample included twenty five volunteering women at the age of retirement, from 64 up to 85 years of age (anthropometry characteristics are presented in Table). All participants were divided into two groups: experimental $(\mathrm{n}=13)$ who underwent strength training program and control group $(\mathrm{n}=12)$. Experimental group underwent an 8 -week strength training program three times a week for one and half an hour. Participants of both groups were tested at the beginning and at the end of the study.

Research methods. At a baseline and after the 8-week training period, participants were weighted using scales (Tanita TBF 300, JAV), the height of the participants was measured using wooden meter ruler. Body Mass Index (BMI) was measured according the formula: $\mathrm{BMI}=\operatorname{mass}(\mathrm{kg}) /$ height (m)2 (Janssen et al., 2002).

Body composition indices were taken using a centimetre measuring tape. For all participants the measures were made at crank web of the dominant hand, chest, waist, hip and femur at the dominant side of the body.

To evaluate the psychical condition of the participants, we used HADS (Hospital Anxiety and
Depression Scale - HADS), which was developed to identify anxiety disorders and depression among patients in non-psychiatric hospital clinics (Bjelland et al., 2002).

To measure upper body muscle strength, we used JAMAR ${ }^{\circledR}$ hydraulic hand dynamometer, hand grip strength was measured in kilograms. We also used a $30 \mathrm{~s}$ arm curl test hanging $2 \mathrm{~kg}$ weight (Rikli, Jones, 2001).

Lower body muscle strength was measured performing $30 \mathrm{~s}$ chair stand test (Rikli, Jones, 2001).

To assess aerobic endurance of legs, we used a 6-min walk test (Rikli, Jones, 2001; Reguero et al., 2009) and a 2-min step test (Rikli, Jones, 2001).

Statistical analysis of the research data was carried out using Microsoft Excel and SPSS (Statistical Package for the Social Science) version 17.0.

The following parameters were calculated: arithmetic mean $(x)$, standard deviation $( \pm \mathrm{SD})$, ANOVA single factor analysis and index $p$ for statistical significance. The level of significance was set when $\mathrm{p}<0.05$.

Table. Anthropometric characteristics of the participants

\begin{tabular}{|c|c|c|}
\hline Index & $\begin{array}{l}\text { Experimental group } \\
\qquad \mathrm{n}=13\end{array}$ & $\begin{array}{c}\text { Control group } \\
n=12\end{array}$ \\
\hline Age, years & $73.5 \pm 7.2$ & $74.7 \pm 6.6$ \\
\hline Height, $\mathrm{cm}$ & $157.9 \pm 5.5$ & $158.1 \pm 6.4$ \\
\hline Wight, kg & $58.5 \pm 8.4$ & $54 \pm 6.4$ \\
\hline
\end{tabular}

\section{RESEARCH RESULTS}

Research results showed that in the experimental group BMI at the beginning was 25.1 (4.5) and after an 8-week strength training program it was 24.8 (3.8), in the control group it was respectively 22.1 (3.5) and 22.1 (3.4). There was no statistically different change in the both groups in BMI. Evaluating body composition measure, we observed only slight changes ( $p>0.05)$.

After the 8-week training period, significant changes were observed in psychical condition in the experimental group. Results showed that anxiety symptoms decreased from 12.0 (2.3) to 9.8 (1.6) after the training period $(\mathrm{p}=0.009)$ and depression symptom values were 11.2 (2.9) at the beginning, and after the 8-week strength training period they decreased to $9.2(1.6),(p=0.04)$ (Figure 1). At the same time the results in the control group slightly improved, but the changes were insignificant $(p>0.05)$. 
Analysis of variance showed a statistically significant difference between the right $(\mathrm{p}=0.00001)$ and left $(\mathrm{p}=0.0004)$ hand dynamometry measurements in the experimental group. Right hand grip results at the beginning were $21.3(3.35) \mathrm{kg}$ and after the strength training period they were 27.4 (2.2) kg, left hand - 20 (3.7) $\mathrm{kg}$ and 25.4 (2.9) $\mathrm{kg}$ (Figure 2). In the control group test results were insignificant $(\mathrm{p}>0.05)$.

$30 \mathrm{~s}$ arm curl test results showed statistically significant changes $(p=0.01)$ only in the right hand results. Results were 13 (3.3) before the training program and 16 (3.2) after an 8-week strength training (Figure 3 ). There were no changes recorded in the control group.

Assessment of lower body strength showed that in the experimental group results improved statistically significantly $(\mathrm{p}=0.003)$. From the 10.5 (2.3) starting strength program and at the end of it 13.3 (2.2) (Figure 4). There was seen the decreasing tendency on the results at the control group, bet there was no statistical different changes.

6-min walk test results showed no significant changes in the aerobic endurance improvement in both groups.

Statistically significant improvement was measured in the experimental group results during a 2-min step test $(\mathrm{p}=0.01)$. At the beginning the result was 63.2 (13.6) and after an 8-week strength training program it was 76.1 (11.3) (Figure 5). We observed decreasing results in the control group from 62.1 (14.8) and to 60.8 (13.4) after the 8 -week period, but the change was insignificant $(\mathrm{p}>0.05)$.
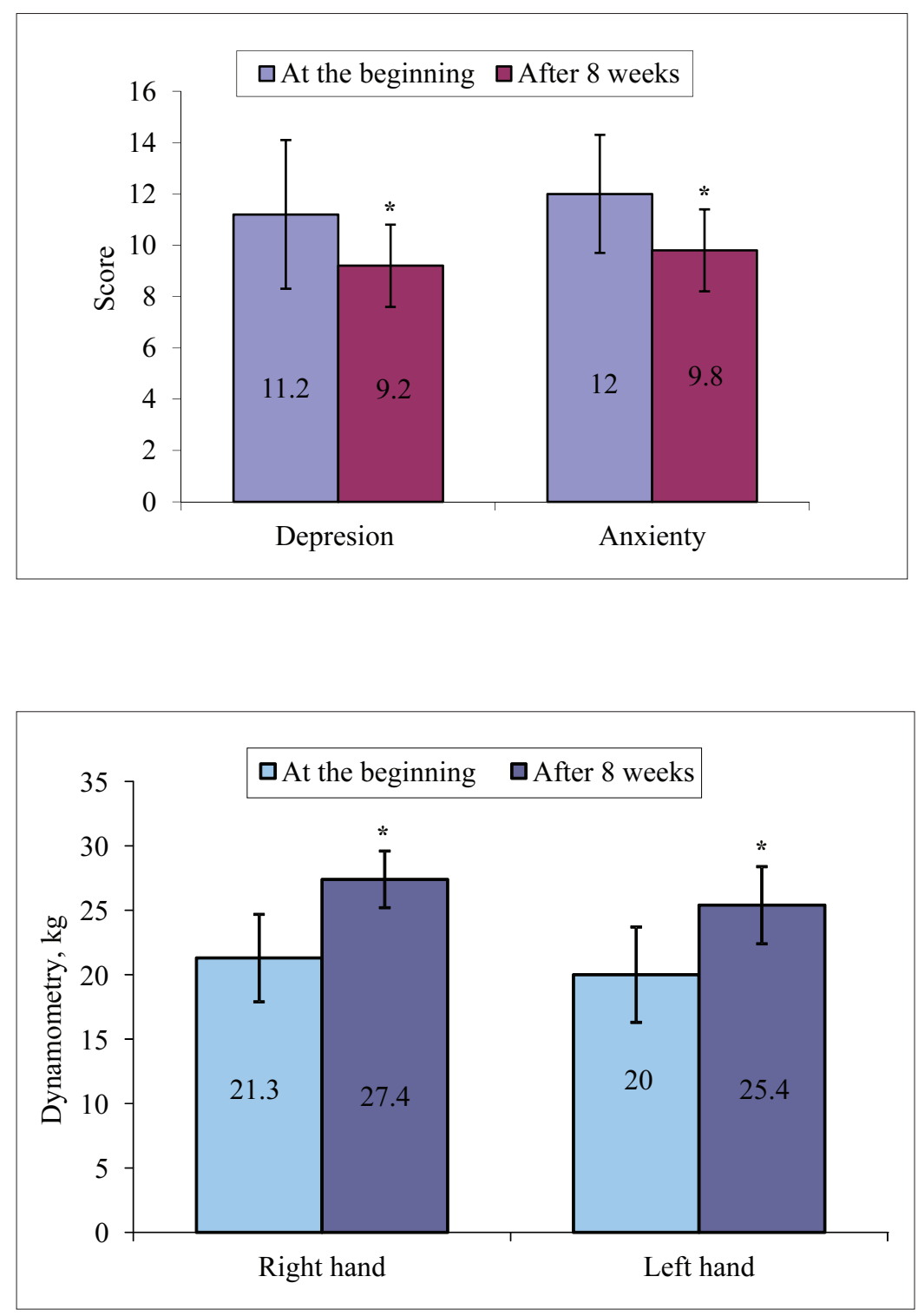

Figure 1. Depression and anxiety symptoms in the experimental group at the beginning and after an 8-week strength training program

Note. * - statistically significant difference $(\mathrm{p}<0.05)$.

Figure 2. Hand dynamometry results in the experimental group at the beginning and after an 8-week strength training program

Note. * - statistically significant difference $(\mathrm{p}<0.05)$. 
Figure 3. $30 \mathrm{~s}$ arm curl test results in the experimental group at the beginning and after an 8- week strength training program

Note. * - statistically significant difference $(\mathrm{p}<0.05)$.

Figure 4. 30 s chair stand test results at the beginning and after 8 -week period in the experimental and control groups

Note. * - statistically significant difference $(\mathrm{p}<0.05)$.

Figure 5. 2-minute step test results at the beginning and after an 8 -week period in the experimental and control groups

Note. ${ }^{*}$ - statistically significant difference $(\mathrm{p}<0.05)$.
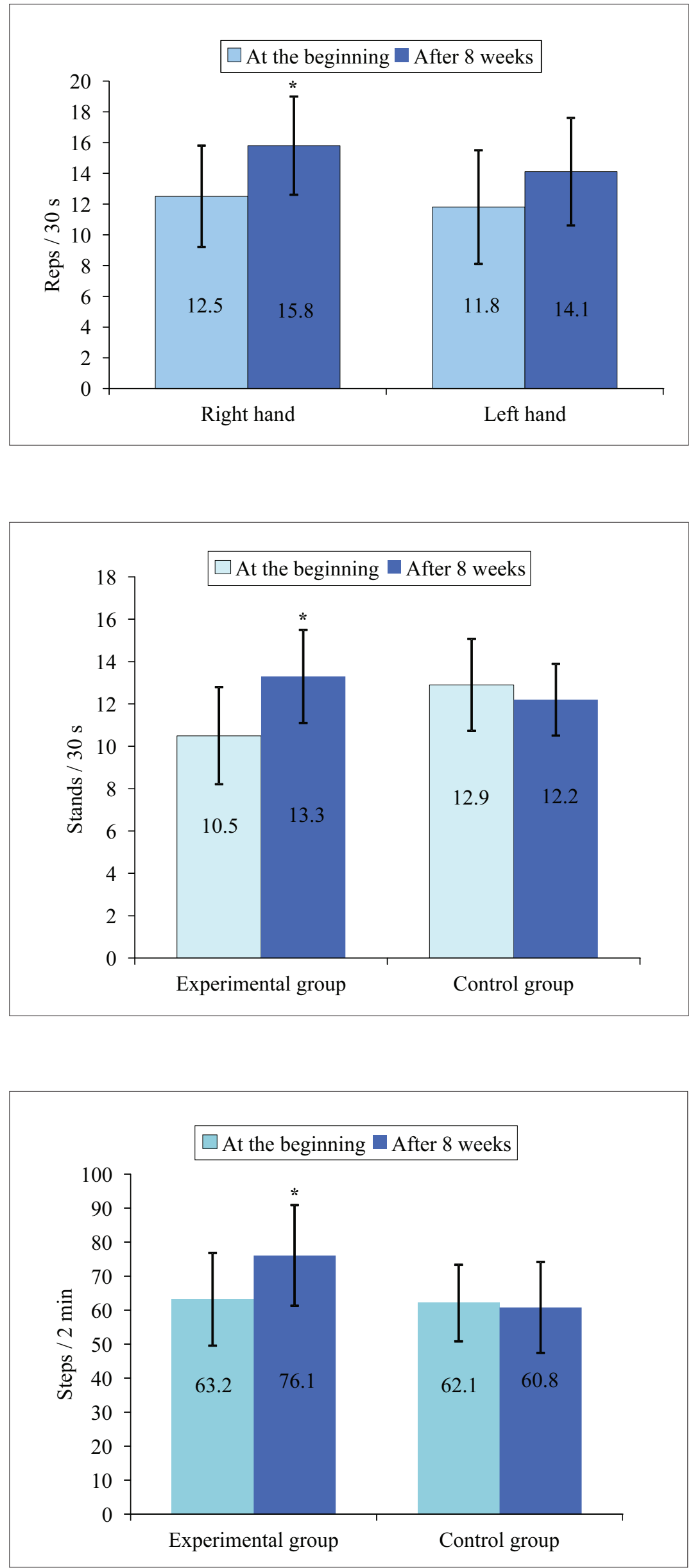


\section{DISCUSSION}

Numerous studies note that physical activity is the one of the methods for elderly people to improve their independent life from other people (Williams et al., 2002; Faulkner et al., 2007; Elsawy, Higgins, 2010; Koster et al., 2011). Adapted strength training program for elderly people improves muscle strength and endurance. An 8-week strength training program results in physical fitness go together with the results of the research made by T. R. Henwood and colleagues (2008). Strength training programs for elderly people gives significant increscent in strength participating $30 \mathrm{~s}$ arm curl test, $30 \mathrm{~s}$ chair stand test and 2-min step test (Bates el al., 2008). Results of 8 -week strength training period showed statistical significant differences in the experimental group results in these tests.

Scientific studies have shown that muscle mass and strength slightly start to decrease from 50 to 80 years of age, but muscle endurance remains unchanged for a longer period of time (Faulkner et al., 2007; Koster et al., 2011). 2-min step test and 6-min walk test purpose is to assess aerobic endurance. Strength training program made positive impact on lower body strength, but there were fewer exercises to improve aerobic endurance. We believe that this is the reason why the results of the 2-min step test increased statistically significant while 6-min walk test results were insignificant in both groups.

A. L. Dunn and colleagues (2002) identified that constant physical loads had a positive impact on psychical condition, improved wellness and had a positive impact on personal motivation. B. Elsawy and K. E. Higgins (2010) found that physically active older adults had lower depression symptoms compared with inactive adults. All these results are similar with our results on the strength training program impact for elderly women's physical condition; we found significant decrease in anxiety and depression symptoms in the experimental group, in this group participants communicated with each other during the training sessions, after each training session there was a discussion about the impact of the exercises and the participants noted that they were in a better mood after the training session. At the same time, we observed slightly improving results in the control group.

After the strength training period, no significant difference in BMI and body composition indices were observed. We believe that this is because of the short time of training period and the impact of nutrition. According to B. Strasser's et al. (2009) 6-month strength and endurance training programme results, there were no significant changes in body weight, but the difference was observed in the percentage of body fat.

\section{CONCLUSIONS AND PERSPECTIVES}

The main finding is that an 8-week strength training period made a significant impact on psychical condition for elderly women. Moreover, strength training exercises improved upper and lower body muscle strength. Endurance improvements were seen during 2-min step test. After the 8-week training period no significant difference in BMI and body composition indices were observed, although there was seen a tendency of slight decrease in the experimental group.

\section{REFERENCES}

Bates, A., Donaldson, A., Lloyds, B. et al. (2009). Staying active, staying strong: Pilot evaluation of once weekly, community - based training program for older adults. Health Promotion Journal of Australia, 20 (1), 42-47.

Bjelland, I., Dahl, A. A., Haug, T. T., Neckelmann, D. (2002). The validity of the hospital anxiety and depression scale: An updated literature review. Journal of Psychosomatic Research, 52, 59-77.

Cornwell, E. Y., Waite, L. J. (2009). Social disconnectedness, perceived isolation, and health among older adults. Journal of Health and Social Behavior, 50 (1), 31-48.
Dunn, A. L., Trived, M. H., Kampert, J. B. , Clark, C. G., Chambliss, H. O. (2002). The DOSE study: A clinical trial to examine efficacy and dose response of exercise as treatment for depression. Controlled Clinical Trials, 23 (5), 584-603.

Elsawy, B., Higgins, K. E. (2010). Physical activity guidelines for older adults. American Family Physician, 81 (1), 55-59.

Faulkner, J. A., Larkin, L. M., Claflin, D. R., Brooks, S. V. (2007). Age - related changes in the structure and function of skeletal muscles. Clinical and Experimental Pharmacology and Physiology, 34, 1091-1096. 
Henwood, T. R., Riek, S., Taaffe, D. R. (2008). Strength versus muscle power - specific resistance training in community - dwelling older adults. Journal of Biological Science of Medicine Science, 63 (1), 83-91.

Janssen, I., Heymsfield, S. B., Ross, R. (2002). Low relative skeletal muscle mass (Sarcopenia) in older persons is associated with functional impairment and physical disability. Journal of the American Geriatrics Society, 50 (5), 889-896.

Koster, A., Ding, J., Stenholm, S. et al. (2011). Does the amount of fat mass predict age-related loss of lean mass, muscle strength, and muscle quality in older adults? The Journal of Gerontology Series A: Biological Science and Medicine Science, 66 A (8), 888-895.

Lietuvos statistikos departamentas. Lietuvos gyventojai $2011 \mathrm{~m}$. [2013 01 12]. Internet link: http://www.stat.gov. 1t/uploads/Lietuvos_gyventojai_2011.pdf
Regueiro, E. M. G., Lorenzo, V. A. P., Basso, R. P., Pessoa, B. V., Jamami, M., Costa D. (2009). Relationshp of body index to functional test in chronic obstructive pulmonary disease. Clinical Science, 64 (10), 983-983.

Rikli, R. E., Jones, C. J. (2001). Senior Fitness Test Manual. Human Kinetics.

Strasser, B., Keinrad, M., Haber, P., Schobersberger, W. (2009). Efficacy of systematic endurance and resistance training on muscle strength and endurance performance in elderly adults - a randomized controlled trial. The Middle European Journal of Medicine, 121, 757-764.

Williams, G. N., Higgins, M. J., Lewek, M. D. (2002). Aging skeletal muscle: Physiologic changes and the effects of training. Physical Therapy, 82, 62-68.

\title{
JĖGOS PRATYBŲ POVEIKIS SENYVO AMŽIAUS MOTERŲ FIZINIAM PAJËGUMUI IR PSICHOLOGINEI SAVIJAUTAI
}

\author{
Vaiva Abramavičiūtė, Kristina Zaičenkovienė \\ Lietuvos sporto universitetas, Kaunas, Lietuva
}

\section{SANTRAUKA}

Tyrimo pagrindimas ir hipotezè. Atlikta nemažai mokslinių tyrimu, kurie įrodo fizinio aktyvumo poveiki asmenų psichinei būklei esant tam tikrai simptomatikai ar ligai. Labai plačiai tyrinèjamas ir fizinès veiklos įtaka asmenų fiziniams gebėjimams, tačiau mažai žinoma tyrimų, kurie nustatytu jẻgos pratybų poveikị senyvo amžiaus moterų psichosocialinei būsenai ir kūno kompozicijos, raumenu jẻgos ir ištvermès pokyčius.

Tikslas - nustatyti jègos pratybų poveikị senyvo amžiaus moterų fiziniam pajègumui ir psichologinei savijautai.

Metodai: literatūros šaltinių analizè, HADS skalè nerimo ir depresijos simptomatikos poreiškiui nustatyti, antropometrija, raumenu jègos ir ištvermès testavimas, rodiklių statistinè analizè. Jègos ir ištvermès testai buvo taikomi pagal senjorų normatyvines skales.

Rezultatai. Nustatyta, kad aštuonių savaičių jẻgos pratybos teigiamai veikia senyvo amžiaus moterų psichologinę būseną. Visų jègos nustatytmo testu rezultatai tiriamojoje grupèje statistiškai reikšmingai pagerèjo $(\mathrm{p}<0,05)$, statistiškai reikšmingi ištvermès pokyčiai užfiksuoti atliekant dviejų minučių žygiavimo vietoje testą. KMI ir kūno apimtys kito mažai $(\mathrm{p}>0,05)$.

Aptarimas ir išvados. Jègos pratybos senyvo amžiaus tarpsniu teigiamai veikia moterų psichologinę būseną. Tyrimo rezultatai parode statistiškai reikšmingus pokyčius. Tiriamojoje grupėje KMI ir kūno apimčių rodikliai statistiškai reikšmingai nepakito, tačiau buvo matoma šių rodiklių mažejimo tendencija. Nustatyta, kad jègos pratybos teigiamai veikia senyvo amžiaus moterų viršutinès ir apatinès kūno dalių raumenų jẻgą. Statistiškai reikšmingi ištvermès pokyčiai užfiksuoti atliekant dviejų minučių žygiavimo vietoje testą.

Raktažodžiai: senyvo amžiaus moterys, jègos pratybos, psichologinè būsena, fizinis pajègumas, aštuoniu savaičiu jègos pratybų programa, HADS skalè, KMI. 